\title{
BIMARU States: Need a Rethinking
}

\author{
Kalyan Sundar Som ${ }^{1}$ Prof. R.P. Mishra ${ }^{2}$ \\ ${ }^{1}$ Research Scholar, General And Applied Geography, Dr. H.S.Gour University, Sagar (M.P.) \\ ${ }^{2}$ Proffesor And Head, General And Applied Geography, Dr. H.S.Gour University, Sagar (M.P.)
}

\begin{abstract}
Need periodically review our population policies objectives, processes, achievements and relevance to keep pace with changing perspectives and discourse on population issues at the national and state level. Now focused on the eight Empowered Action Group (EAG) states of Bihar, Jharkhand, Madhya Pradesh, Chhattisgarh, Rajasthan, Orissa, Uttar Pradesh and Uttarakhand where reach the unserved, underserved areas, vulnerable and marginalized populations. Since mid 80 Asish Bose, 'BIMARU' are still prevailed in the lower section of demographic transition. What the matter persist in this area, why special policy on EAG states are not much effective. This says that the time is come to rethinking the problem of EAG states.
\end{abstract}

Key words: EAG states, BIMARU, Demographic transition, Population Policy.

\section{Introduction:}

In the mid 80s, economist analyst Ashis Bose coined an acronym BIMARU, in a paper submitted to then Prime Minister Rajiv Gandhi. BIMARU has a resemblance to a Hindi word "Bimar" which means sick. This was used to describe the bad state of economy in backward states Bihar, Madhya Pradesh, Rajasthan, and Uttar Pradesh. Later Odisha was included in the list. Several studies, including those by the UN, showed that the performance of the BIMRU states affected the GDP growth rate of India. Some of these states are also red corridor.

The difference in economic and population growth rates between the BIMARU states and other Indian states sharpened over the 1990s. The economy of four BIMARU states grew at an average of $4.6 \%$ per year in the $1990 \mathrm{~s}$, compared to $6.5 \%$ per year for India as a whole. Since population growth in the BIMARU states was much higher than the Indian average in this period, the income disparity between the BIMARU states and India as a whole also increased.

\section{Study Area:}

The most conspicuous feature of the demographic characteristics of the EAG states (former BIMARU states) is its high fertility, high IMR, high MMR, high population growth rate and low literacy rate and high literacy gender differential is occurred. The plains of Ganga, Yamuna, Narmada, Mahanadi present support near about two third of the population of the region which is also a high density region. This has led to high density and concentration of population in certain districts while the rest of the region is sparsely populated. It is estimated that the population of the region in 1951 was only 13.43 million. In 2011 the region had a population of 555175135 persons indicating a decadal growth rate of near 25 percent on the face of national decadal growth rate of 17.64 percent. The growth rate varies states to states. The highest growth rate took place in the state of 25.07 , nearly 7.63 high growth rate than national average or higher than one and half fold than Kerala growth rate. The uneven distribution of population is mainly due to diverse physiographic conditions and disparity in the socio-economic development that the region has experienced in recent decades. The high growth rates are attributed to high fertility rate in this region. This phenomenal increase in population has great impact not only on the demographic composition of the region but also has serious socio-economic consequences which gets reflected in political turmoil and consequent conflicts witnessed in the entire region.

An attempt has been made in this study to examine the determinants for this unusually high fertility rate of population, the present distribution pattern and some demographic, socio-economic and environmental implications arising out of this. 


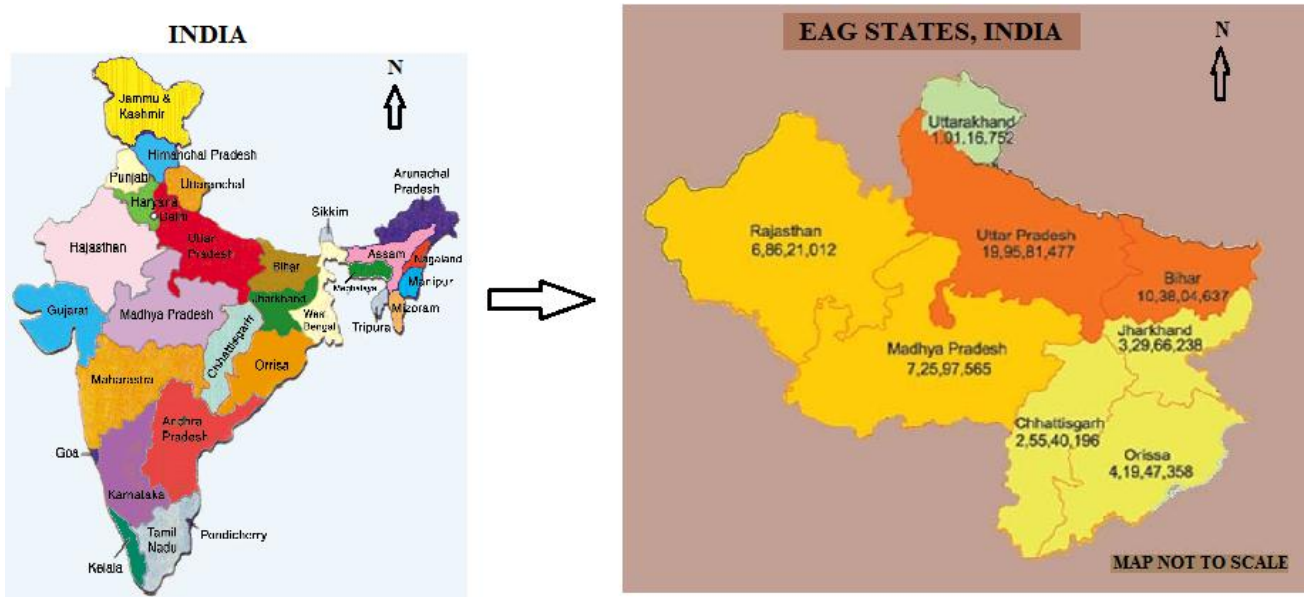

\section{Location Map of EAG State}

\section{Objectives:}

1. To know the present condition of EAG states, India.

2. Is EAG states have improved in his condition or not in last decade?

\section{Data Base and Methodology:}

- The paper is based on secondary data sources. To fulfill the objectives data regarding literacy, urbanization, sex ratio and other demographic variables of EAG states are obtained from census of India (2011), planning commission report on March 2012, SRS 2008, 2009 and 2010, NFHS 2005-06 and Family welfare statistics, 2011.

- The collected data are processed to analyze the literacy differential index, pattern of population density and growth and sex ratio in EAG states

- Suitable maps and diagrams are used to illustrate the facts.

- For this study information has been collected with the help of books, magazines, research articles and report of national census.

\section{Growth Rate:}

population growth is the main problem in this states. Due to high population growth, population and resource are unequlibrium, that are distrubed to achived the goal of population satbilization and sustainable development.

\begin{tabular}{|c|c|c|c|c|}
\hline $\begin{array}{r}\text { SL } \\
\text { NO. }\end{array}$ & STATE NAME & 2001 & 2011 & $\begin{array}{l}\text { CHAN } \\
\text { GE }\end{array}$ \\
\hline 1 & BIHAR & 28.62 & 25.1 & 3.52 \\
\hline 2 & JHARKHAND & 23.36 & 22.3 & 1.06 \\
\hline 3 & UTTAR PRADESH & 25.91 & 20.1 & 5.81 \\
\hline 4 & RAJASTHAN & 28.41 & 21.4 & 7.01 \\
\hline 5 & CHHATTISGRAH & 18.27 & 22.6 & -4.33 \\
\hline 6 & $\begin{array}{l}\text { MADHYA } \\
\text { PRADESH }\end{array}$ & 24.26 & 20.3 & 3.96 \\
\hline 7 & UTTARKHAND & 19.34 & 19.2 & 0.14 \\
\hline 8 & ORISSA & 16.25 & 14 & 2.25 \\
\hline 9 & INDIA & 21.53 & 17.64 & 3.89 \\
\hline
\end{tabular}

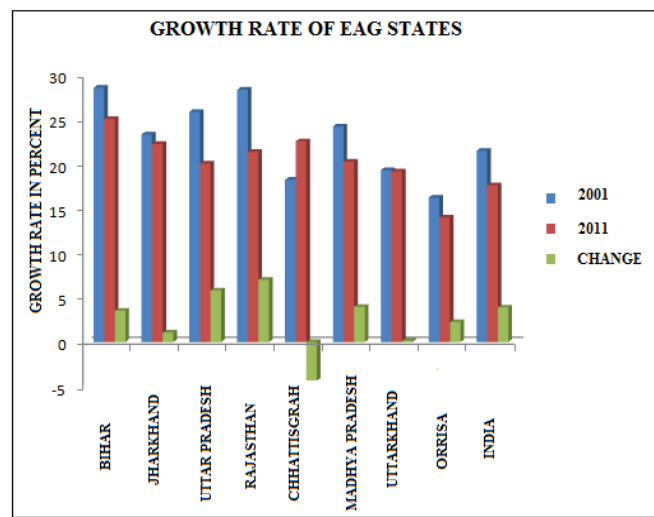

Source: COI, $2001 \& 2011$.

\section{Population Density:}

Among EAG states, Bihar is the most densely populated state whereas; Uttarakhand and Chhattisgarh with density of 189 each are the least densely populated states. Madhya Pradesh is fifth among 8 EAG states with moderate density. Among EAG states; Bihar, Uttar Pradesh and Jharkhand have higher density of population than that of India in 2011. 


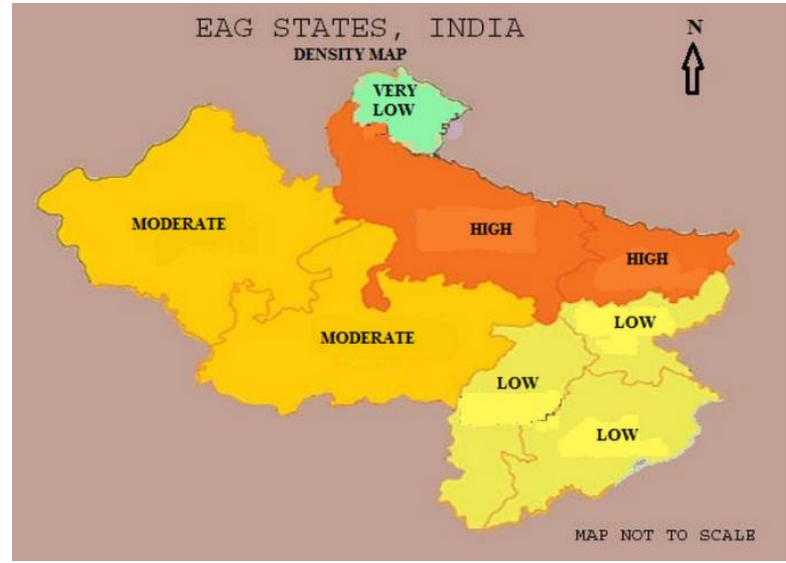

V. Literacy Rate:

The literacy rates in these states according to the 2011 census are Bihar $63.82 \%$, Odisha $73.45 \%$, Rajasthan 67.06\%, Jharkhand 67.63\%, Madhya Pradesh 70.63\%, Uttar Pradesh 69.72\%\%, Chhattisgarh 71.04\%, and Uttarakhand $79.63 \%$ against national average of $74.04 \%$. While they are the trail the national average in the current literacy rate, they are registering very healthy growth rates in literacy comfortably outpacing states like Andhra Pradesh (67.66 \%) and Arunachal Pradesh (66.95\%) and Jammu and Kashmir (68.74\%), which have comparable literacy levels.

A recent survey by national University Planning and Administration or UNEPA has determined that quality of teachers in BIMARU states is better than all India. Only $21 \%$ of all primary school teachers in Bihar and Uttar Pradesh are matriculates or lower. The rest are better educated. These figures are comparing favourably with other developed states with Gujarat being the lowest and Karnataka are relatively more advanced. Thus, the reason as to why the BIMARU states are poorer may not be attributed to literacy rates.

\begin{tabular}{|l|l|l|l|l|l|}
\hline SLNO. & STATE NAME & $\begin{array}{l}\text { MALE } \\
\text { LITERACY }\end{array}$ & $\begin{array}{l}\text { FEMALE } \\
\text { LITERACY }\end{array}$ & $\begin{array}{l}\text { OVERALL } \\
\text { LITERACY } \\
\text { RATE }\end{array}$ & $\begin{array}{l}\text { LITERACY } \\
\text { DIFFERENTIAL } \\
\text { INDEX }\end{array}$ \\
\hline 1 & BIHAR & 73.39 & 53.33 & 63.82 & 0.31 \\
\hline 2 & JHARKHAND & 78.45 & 56.21 & 67.63 & 0.33 \\
\hline 3 & UTTARPRADESH & 79.24 & 59.06 & 69.72 & 0.29 \\
\hline 4 & RAJSTHAN & 80.51 & 52.66 & 67.06 & 0.42 \\
\hline 5 & CHHATTISGRAH & 81.45 & 60.59 & 71.04 & 0.29 \\
\hline 6 & MADHYA PRADESH & 80.53 & 60.02 & 70.63 & 0.29 \\
\hline 7 & UTTARKHAND & 88.33 & 70.70 & 79.63 & 0.22 \\
\hline 8 & ORRISSA & 82.40 & 64.36 & 73.45 & 0.25 \\
\hline 9 & INDIA & 82.1 & 65.46 & 74.04 & 0.22 \\
\hline
\end{tabular}

Source: COI, 2011
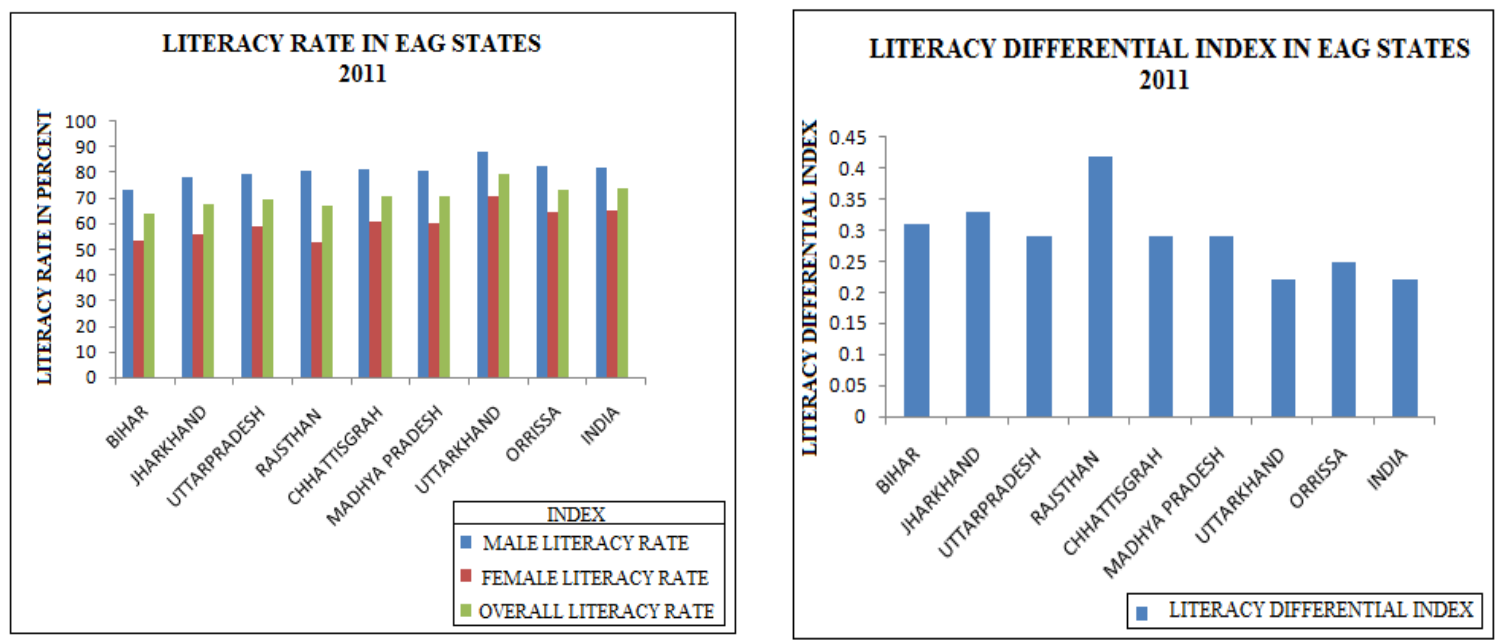


\section{Education in EAG States:}

A recent survey by National University of Educational Planning \& Administration or UNEPA has determined that quality of teachers in BIMARU states is better than all India. Only $21 \%$ of all primary school teachers in Bihar and $12.8 \%$ in UP are Matriculates or lower. The rest are better educated. These figures compare favourably with other developed states with Gujarat being the worst and Karnataka being the second worst. However, this is some sort of an enigma because the states of Gujarat and Karnataka are relatively more advanced. Thus, the reason as to why the BIMARU states are poorer may not be attributed to literacy rates.

Renowned educationists have asked for a complete overhaul of the educational system, particularly at the primary level.

\section{Son Preference with Declining Fertility Trends in EAG States:}

One much-anticipated census figure has seen a lot of attention in the Indian press. The sex ratio of the child population ages 0 to 6 declines from 927 females per 1000 males in 2001 to 914 in 2011. While not a large decrease, the change is in the wrong direction, showing a growing preference for sons. In China, there are about 833 female births per 1000 males. Normally, the ratio would be about 950 because biologically there are about 5 percent or 50 more male births worldwide than female. In India as well as in China and some western Asian countries, the preference for sons has resulted in the abortion of female fetuses and poorer nutrition and health care for girls. In India, sons are preferred for the economic support they provide for the household, particularly in their parents' old age. Daughters are not seen as a source of financial support, especially since they leave the parental home to live with their husband's family after marriage. In addition, parents of daughters must still pay a dowry, despite the practice being illegal since 1961. A telling saying in India is: Having a daughter is like "watering your neighbor's garden." Another reason for the abortion of females is the desire of many Hindus to have a son who will light their funeral pyre. Sex-selective abortion was criminalized in 1994 but serious enforcement of the law was rare until recently. The National Commission for Women, established in 1992, oversees all women's rights issues, particularly female infanticide and sex-selective abortion.

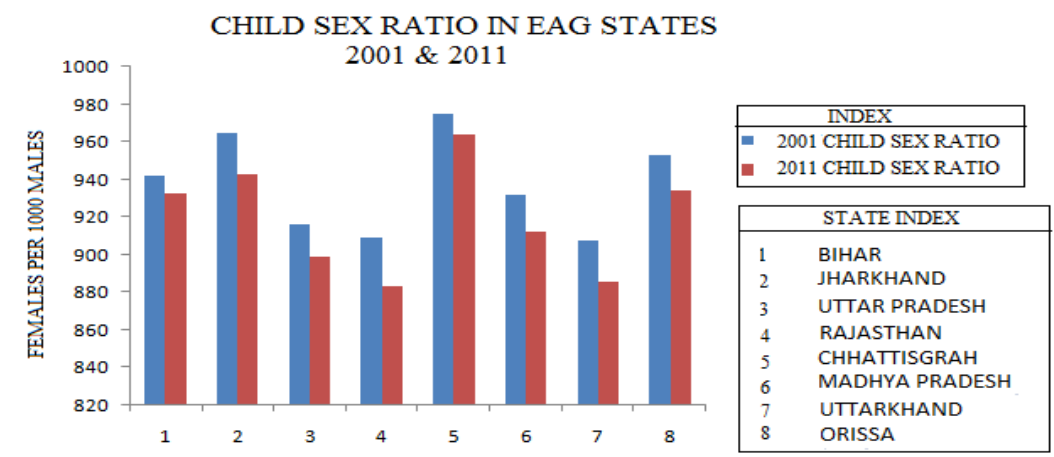

The national figure masks a more skewed sex ratio in several states. Declining fertility has increase the son preference, which has been proved by the last 10 years data especially in EAG states, because most of the couple wants a son for old age security. That's why sex selective abortion is increase. In EAG states last ten years child sex ratio declining a range 9 to 26, where 9 in Bihar and 26 in Rajasthan, median of declining child sex ratio is 19. On the other hand sharp decline in TFR is observed in EAG states. Between 2003 to 2011 median decline TFR is 0.6 per women that is same of the Indian average.

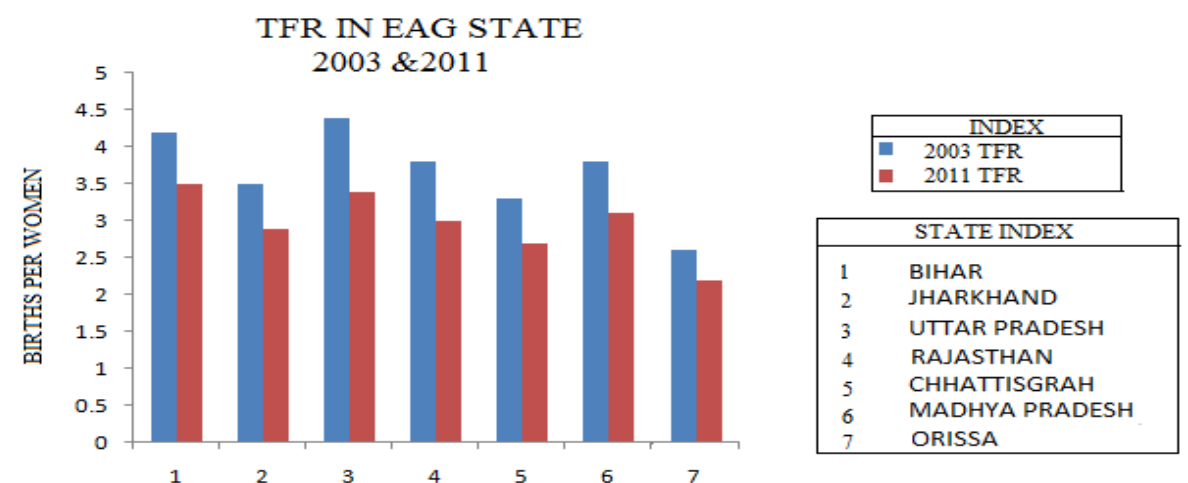




\begin{tabular}{|c|c|c|c|c|c|}
\hline \multicolumn{2}{|c|}{ EAG STATES } & \multicolumn{2}{|c|}{ CHILD SEX RATIO } & \multicolumn{2}{|c|}{ TFR } \\
\hline $\begin{array}{c}\text { SL } \\
\text { NO. }\end{array}$ & STATE NAME & 2001 & 2011 & 2003 & 2010 \\
\hline 1 & BIHAR & 942 & 933 & 4.2 & 3.7 \\
\hline 2 & JHARKHAND & 965 & 944 & 3.5 & 3 \\
\hline 3 & UTTAR PRADESH & 916 & 899 & 4.4 & 3.5 \\
\hline 4 & RAJASTHAN & 909 & 883 & 3.8 & 3.1 \\
\hline 5 & CHHATTISGRAH & 975 & 964 & 3.3 & 2.8 \\
\hline 6 & MADHYA PRADESH & 932 & 912 & 3.8 & 3.2 \\
\hline 7 & UTTARKHAND & 908 & 883 & & \\
\hline 8 & ORISSA & 953 & 934 & 2.6 & 2.3 \\
\hline
\end{tabular}

Source: Census of India and Family welfare statistics in India (2011).

These trends create more social evils and move the society towards destruction. Human awareness and moral thought is the only tonic with active law against the abortion to stop this move towards demographic Dark Age.

\section{Female Literacy, Mean Age at Marriage and Total Fertility Rate in EAG States:}

Education is an important factor in accounting for fertility differences within population in a given area. It has prime importance in investigative work both as concern differential fertility by socio economic status and in the search for casual explanations of fertility levels and fertility changes. Knowledge of educationfertility relationship is especially relevant for relevant for development planning because education can be directly influenced by the government policy. In our country where high fertility is considered an obstacle to development, detailed knowledge of the education fertility relationship would doubtlessly facilitate decision concerning education levels, curriculum content, the structured of educational system and ultimately the division of resources between education and other competing programmes.

Conceptually, education a homogenous commodity whose only important attribute is level reached (Ridker 1976, Cochrane 1979, Hermakin and Masin 1980). while educational content may not be as important as educational attainment in certain hypothesized causal paths linking education with fertility (such as postponement of marriage), it is clearly so, with regards to those effects on fertility which operate through changes in attitude, self perception and the productivity of human capital.

Age at marriage has been considered as a promising determinant of fertility, which has several policy implications (Audinarayana 1986). Late marriage reduces fertility because it shortens the reproductive period. If contraception is not widely and expertly practiced, marriage postponement may be contributed substantially to the lowering of birth rate (Blake, 1961). In a situation of limited control of fertility within marriage, a negative association between age at marriage and family size is generally considered almost inheritable. It has also been emphasized by many workers (Davis, 1967 and Berelson, 1969) that voluntary family planning programme are not enough as first step in population control and that change in the marital patterns are necessary both as long and short term solution to the problem of population pressure. At the world population conference 1974 (United Nations, 1978), it was argued that family planning alone is not enough to curb the fertility. Therefore certain measures beyond family planning measures were also advocated. The late marriage has been considered as the most important and potentially useful measures to control fertility level. The present study also shows an inverse correlation between marriage age and fertility.

Table no. 1: TFR, median age at marriage and female literacy rate of EAG states

\begin{tabular}{|c|c|c|c|c|c|c|c|}
\hline \multirow{2}{*}{\multicolumn{2}{|c|}{ EAG STATES }} & \multirow{2}{*}{\multicolumn{3}{|c|}{$\begin{array}{l}\text { TFR } \\
\text { SRS }\end{array}$}} & \multicolumn{2}{|c|}{$\begin{array}{l}\text { MEDIAN AGE AT } \\
\text { MARRIAGE }\end{array}$} & \multirow{3}{*}{$\begin{array}{l}\text { FEMALE LITERACY } \\
\text { RATE } \\
\text { CENSUS OF INDIA } \\
2011\end{array}$} \\
\hline & & & & & NFHS(2005-06) & AHS(2010) & \\
\hline SL NO. & STATE NAME & 2008 & 2009 & 2010 & WOMEN & WOMEN & \\
\hline 1 & BIHAR & 3.9 & 3.9 & 3.7 & 15 & 19.7 & 53.33 \\
\hline 2 & JHARKHAND & 3.2 & 3.2 & 3 & 16.2 & 20.2 & 5621 \\
\hline 3 & UTTAR PRADESH & 3.8 & 3.7 & 3.5 & 16.2 & 21 & 59.26 \\
\hline 4 & RAJASTHAN & 3.3 & 3.3 & 3.1 & 15 & 19.7 & 52.66 \\
\hline 5 & CHHATTISGRAH & 3 & 3 & 2.8 & 16.4 & 20.9 & 60.59 \\
\hline 6 & $\begin{array}{l}\text { MADHYA } \\
\text { PRADESH }\end{array}$ & 3.3 & 3.3 & 3.2 & 15.9 & 20.6 & 60.02 \\
\hline 7 & UTTARKHAND & & & & 15 & 22 & 70.7 \\
\hline 8 & ORISSA & 2.4 & 2.4 & 2.3 & 17.9 & 21.7 & 64.36 \\
\hline
\end{tabular}

Source: SRS (2008, 2009, 2010), NFHS (2005-06), AHS (2010), COI (2011). 
MODEL-1

INDIPENDENT VARIABLES

PROXIMATE VARIABLES

DEPENDENT VARLABLE

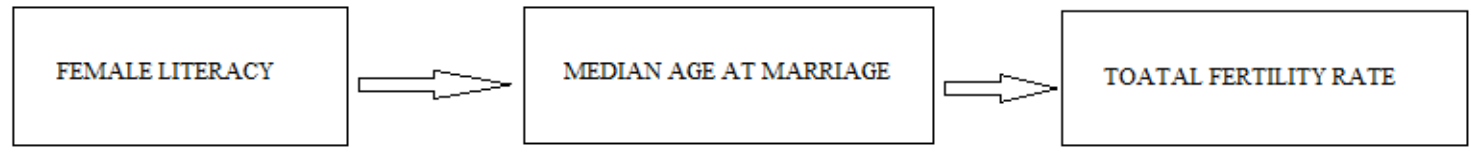

RELATION OF FEMALE LITERACY, MEDIAN AGE AT MARRIAGEAND TFR

IX. Sex Selective Abortion:

In 2001, India had 158 million infants and children, of which 82 million were males and 76 million, were females. There was a deficit of 6 million females infants and girls. This is a result of the widespread use of sex determination and sex pre-selection tests throughout the country (including Kerala), along with rates of female infanticide in BIMARU states. Millions of girls have been missing in the post independence period. According to UNFPA and RGI (2003), 70 districts in 16 states and union territories recorded more than a 50 point decline in the child sex ratio in the last decade.

To stop the abuse of advanced scientific techniques for selective elimination of female fetuses through sex determination, the government of India passed the PNDT Act in 1994. (vibhuti patel 2007)

This perverse use of modern technology is encouraged and boosted by money-minded private practitioners who are out to make Indian women 'male-child-producing machines'. In fact, a shortage of women in Haryana, Punjab and the BIMARU states has escalated forced abduction and kidnapping of girls, forced polyandry, gang rape and child prostitution.

Diametrically opposite views come from Dr. Anniruddha Malpani, the most articulate proponent of sex-pre-selection tests. When asked, 'Is it ethical to selectively discard female embryos?' he said, 'where does the question of ethics come in here? Who are we hurting? Unborn girls?'(Banerjee, 2001). My questions are: can we allow Indian women to become an endangered species? Shall we be bothered only about endangered wildlife, tigers, lions, so on and so forth? Massive resources are invested in OPERATION TIGER. When shall we start OPERATION GIRL CHILD?

\section{Anemia among Women in EAG States:}

In India, the prevalence of anemia among women of age group 15-49 years is much higher and it is necessary to see the effect of lifestyle behaviors on women's anemia level for better understanding of women's health in eight empowered action group (EAG) states.

This research investigates the prevalence and determinants of anemia among women in EAG states. The researcher has examined the effect of lifestyle variables on the anemia level of women of age group 1549 years in EAG states. This study utilizes the data obtained from National Family Health Survey (NFHS-3, 2005-06).

Prevalence of anemia was high among all women. About $40.0 \%$ of women had mild, $13.0 \%$ had moderate, and $1.4 \%$ had severe anemia. Those women who belong to the 15-19 year age group, no and low education, poorest quintile and 3+ children are significantly more likely to be anemic. Those women who are under weight, have been working in the past years, smoke and chew tobacco, have no exposure to mass media and never eating pulses and fruits are found to be more anemic.

\section{Urbanization in EAG States:}

\begin{tabular}{|l|r|r|r|}
\hline \multicolumn{4}{|c|}{ URBANIZATION } \\
\hline \multicolumn{1}{|c|}{ NAME } & $\mathbf{2 0 0 1}$ & $\mathbf{2 0 1 1}$ & \multicolumn{1}{c|}{ CHANGE } \\
\hline BIHAR & 10.5 & 11.3 & 0.8 \\
\hline JHARKHAND & 22.2 & 24.05 & 1.85 \\
\hline UTTARPRADESH & 20.8 & 22.28 & 1.48 \\
\hline RAJASTHAN & 23.4 & 28.89 & 5.49 \\
\hline CHHATTISGARH & 20.1 & 23.24 & 3.14 \\
\hline MADHYA PRADESH & 26.5 & 27.63 & 1.13 \\
\hline UTTARAKHAND & 25.7 & 30.55 & 4.85 \\
\hline ORISSA & 15 & 16.68 & 1.68 \\
\hline INDIA & 27.8 & 31 & 3.2 \\
\hline
\end{tabular}

Source: Census of India, 2001\&2011.

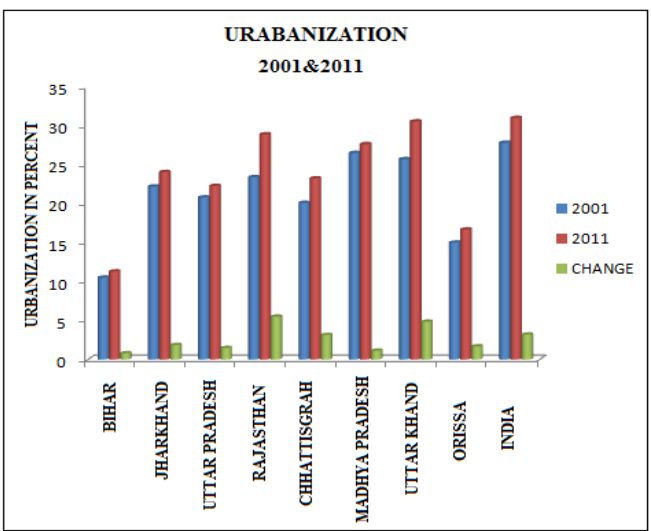


Urbanization in India was mainly caused after independence, due to adoption of mixed system of economy by the country which gave rise to the development of private sector. Urbanization is taking place at a faster rate in India.

Population residing in urban areas in India, according to 1901 census, was $11.4 \%$. This count increased to $28.53 \%$ according to 2001 census, and crossing $30 \%$ as per 2011 census, standing at $31.16 \%$. According to a survey by UN State of the World Population report in 2007, by 2030, $40.76 \%$ of country's population is expected to reside in urban areas. As per World Bank, India, along with China, Indonesia, Nigeria and the United States, will lead the world's urban population surge by 2050.

\section{Poverty:}

Poverty in India is widespread. In 2012, the Planning Commission reported that $21 \%$ of all people in India fall below the international poverty line of US\$ 1.25 per day (PPP) Poverty ratio in the country has declined to $21 \%$ in $2011-12$ from $37.2 \%$ in 2004-05.

Over the last decade, poverty has witnessed a consistent decline with the levels dropping from $37.2 \%$ in 2004-05 to $29.8 \%$ in 2009-10 \& Now $21 \%$ in 2011-12. The number of poor is now estimated at 269.3 million, of which 216.5 million reside in rural India. According to 2010 data from the United Nations Development Programme, an estimated $29.8 \%$ of Indians live below the country's national poverty line. A 2010 report by the Oxford Poverty and Human Development Initiative (OPHI) states that 8 Indian states have 421 million poor people more poor people than Sub-Saharan Africa. A 2013 UN report stated that a third of the world poorest people live in India.

According to 2011 poverty Development Goals Report, as many as 320 million people in India and China are expected to come out of extreme poverty in the next four years, with India's poverty rate projected to drop from $51 \%$ in 1990 to about $22 \%$ in 2015 . The report also indicates that in Southern Asia, only India is on track to cut poverty by half by the 2015 target date.

The current methodology for poverty estimation is based on the recommendations of an Expert Group to Review the Methodology for Estimation of Poverty (Tendulkar Committee) established in 2005.

\begin{tabular}{|l|r|}
\hline \multicolumn{2}{|c|}{ POVERTY } \\
TENDULKAR METHODOLOGY \\
\hline NAME & $\begin{array}{l}\text { 2009- } \\
\text { 2010 }\end{array}$ \\
\hline BIHAR & 53.5 \\
\hline JHARKHAND & 39.1 \\
\hline UTTARPRADESH & 37.7 \\
\hline RAJASTHAN & 24.8 \\
\hline CHHATTISGARH & 48.7 \\
\hline MADHYA & 36.7 \\
\hline PRADESH & 18.0 \\
\hline UTTARAKHAND & 37.0 \\
\hline ORISSA & 29.8 \\
\hline INDIA & \\
\hline
\end{tabular}

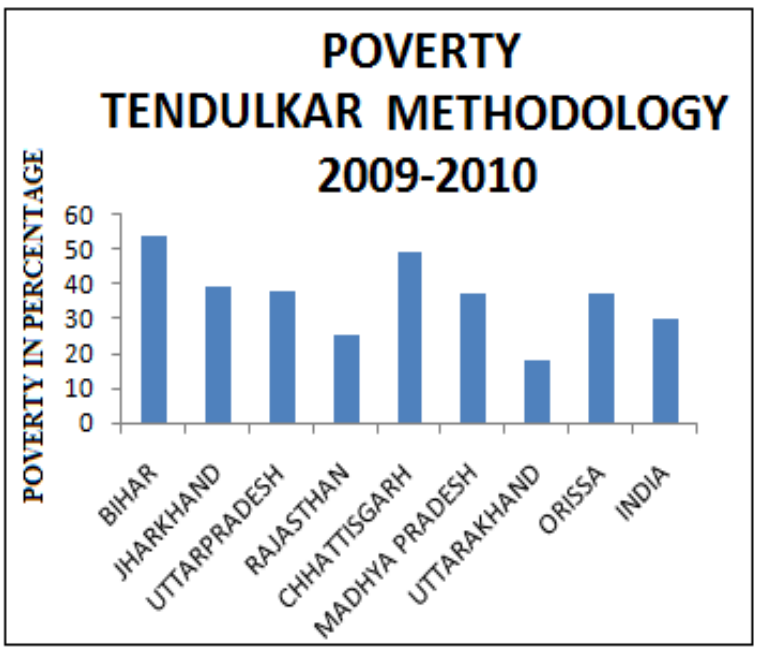

Source: GOI, Planning Commission, Press Release, March 20, 2012

The Committee calculated poverty levels for the year 2004-05 and also calculated poverty levels for the year 1993-94 using the same method to enable comparison over time. Poverty levels for subsequent years are calculated on the basis of the same methodology, after adjusting for the difference in prices due to inflation.

\section{Conclusion:}

In concluding part, these think is clear they are still lag behind than other Indian states on the basis of literacy, education, urbanization and income. On the other hand, they are very high fertility and low reproductive health of women.

Chhattisgarh and Jharkhand some portion are Maoist affected, these area are mainly forest covered and native tribes are belong. That's why this are need to special attention on Chhattisgarh and Jharkhand both the mineral rich states.

Uttar Pradesh, Madhya Pradesh and Bihar main problem is heavy fertility and high number of child population, that's creating obstacle to upward stage of demographic transitions. 
Orissa have high poverty and high mortality due to shortage of food and nutrition, especially tribal group.

Undulation tract and most active sudden force in Uttarakhand tend to obstacle the economic up gradation of this state.

XIV. Policy Recommendations:

Need to tackle high fertility, government work in a Bangladesh family planning approach model with united nation population group and NGOs.

Reduce poverty by a community approach, on a self help group formula. To increase food production in a sustainable way that reduces the environmental loss and produce a long terms perspective.

Government need to a crude action among the female feticide and abortion case that increase child sex ratio in those states.

\section{Acknowledgement}

The author is grateful to professor Ashis sarkar, former head of the department of geography in presidency university, Kolkata for constant motivation and encouragement to complete this work.

\section{References}

[1]. "Don’t call them Bimaru States now”, Hindustan Times. Com, July 19, 2010.

[2]. Bose, Ashis - The man who coined the term "Bimaru". (www. Livemint. com).

[3]. "Bimaru or bimari?", The Hindu, 12 August 2005 (www.Thehindubusinessline.com/2005).

[4]. UNEPA report on education on EAG states.

[5]. Census of India, 2011

[6]. National Family welfare statics, 2011.

[7]. Sample registration system report 2008, 2009 and 2010.

[8]. “Anemia on EAG states", a paper present on IIPH seminar 2004.

[9]. Patel, Vibhuti, (2010), "Abortion in EAG states" Sage publication.

[10]. Kingsley Davis, Judith Blake (1956), "Social structure and fertility-an analytical framework” weliy, London. 